\title{
High-tech exports from developing countries: A symptom of technology spurts or statistical illusion? *
}

\author{
Martin Srholec \\ Centre for Technology, Innovation and Culture (TIK) \\ University of Oslo \\ TIK Working Papers on Innovation Studies \\ December 2005
}

\begin{abstract}
Specialization in high-tech products is frequently used to capture technology intensity of exports. The literature suggests that developing countries are increasingly becoming exporters of high-tech products, and some may even be among the most deeply specialized countries in the field of high-tech exports. The paper scrutinizes the relevance of the taxonomies that classify exports by technological intensity in this context. It is shown that specialization in high-tech exports typically does not appear in tandem with indigenous technological capabilities in developing countries. The analysis of intra-product imports suggests that the bulk of high-tech exports can actually be attributed to the effect of increasingly international fragmentation of production systems in electronics on trade statistics. It is confirmed in an econometric framework that while domestic technological capabilities have some influence on export performance in electronics, it is the propensity to import electronics components that accounts for by far the largest proportion of cross-country differences in specialization in electronics exports. The paper concludes with some implications for policy and future research.
\end{abstract}

JEL classification: F10, O10, O30.

\footnotetext{
* I am grateful to the Norwegian Research Council for providing financial support through the research project "Globalisation as a transformative force". I thank Jan Fagerberg, Mark Knell, Fulvio Castellacci, Jarle Hildrum, Slavo Radoševič, Luc Soete, Bent Dalum and Sunil Mani for comments and suggestions to the earlier drafts of the paper. All usual caveats apply.
} 


\section{Introduction}

The possibility that specialization in technologically intensive activities matters for economic development is well established in the literature on technological change. It is stressed in the Schumpeterian literature that prospects for productivity growth differ across activities because of differences in technological opportunities (Schumpeter 1934, Nelson and Winter 1982, Verspagen 1993 and Fagerberg 2002). The Post-Keynesian perspective that specialization in some segments of international demand provides better growth prospects because of higher income elasticity can also be interpreted as reflecting differences in quality and technological intensity (Fagerberg 1988 and Dalum, Laursen and Verspagen 1999).

It is therefore not surprising that specialization in exports of products generally perceived as high-tech frequently appears in comparative studies by international organizations, governmental bodies and other institutions (UNDP 2001, UNIDO 2002, UNCTAD 2002ab, NSF 2002, OECD 2003 and IMD 2005) as well as in academic research on technology, trade and growth (Guerrieri and Milana 1995, Fagerberg 1997, Mani 2000, Lall 2000, Kadeřábková and Srholec 2001 or Srholec 2006). The empirical literature confirms that high-tech products are the fastest growing segment of international trade. Moreover, there is strong evidence that developing countries are increasingly becoming exporters of high-tech products. It is particularly convenient to use the share of high-tech products in exports as a proxy for the technological intensity of local export bases in developing countries because the information is available for virtually every country with trade statistics, while evidence on other measures directly reflecting technology, such as those based on R\&D or innovation surveys, still remains scarce. 
Although frequently applied in the literature, we still find little discussion of the relevance of the various taxonomies of industries and products by technological intensity for cross-country comparisons. It is typically assumed that high-tech exports reflect the technological intensity of the local business activity, with limited attention given to the possibility that actual technological content may differ across countries. As some have already remarked, the direct link between the focus of export specialization and local technological capabilities cannot be taken for granted, particularly in the context of latecomer countries. Lall (2000) directly notes that a significant part of the high-tech industry outbreak in developing countries might be "something of a statistical illusion", as they specialize in labour-intensive processes within high-tech-intensive industries. Similarly, Mayer, Butkevicius, and Kadri (2002) suggest that the expansion of high-tech exports from developing countries is largely because of their increased participation in labour-intensive segments of high-tech electronics in the context of international production sharing. Despite these reservations, however, the studies focus on the structure of exports without many further concerns.

A further step in this vein is taken by Mani (2000), who investigated directly whether the surge of high-tech exports from developing countries is "real or rather a statistical artefact". The paper focused on patenting activity in newly industrialized Asian countries. The main finding is that only two of them, namely Korea and Taiwan, had any significant number of patents in the high-tech fields, whereas the other major exporters of high-tech products from Asia had fairly limited patenting records. However, the study concludes that these countries as a whole were rapidly catching up, so it might be unwise to write off their performance as a mere statistical artefact. Srholec (2006) looks beyond the Asian countries and focuses in detail on the role of international production sharing for high-tech exports. This study suggests that 
many latecomer countries experienced a rapid growth of high-tech exports, but gained little in terms of contribution to upgrading of local technological capabilities.

This paper further re-examines the indicator of high-tech exports by means of a detailed quantitative analysis of the "statistical illusion" hypothesis in a large sample of countries. The next section briefly outlines the methodology of the industry-based taxonomies of technological intensity and highlights some of their main caveats, particularly in the light of the increasing international fragmentation of production. The empirical analysis starts with a cross-country comparison of specialization in high-tech exports as typically done in the existing literature. A simple comparison with intensity of R\&D expenditure reveals, however, that the indicator in many cases has a little to do with indigenous technological capabilities. It is further shown that electronic goods in particular account for the bulk of high-tech exports from most countries.

We therefore search for other explanatory factors of export specialization in electronics. We focus on a possible role of the deepening fragmentation of value chains across the globe by establishing a distinction between trade in final electronics products and in their components. The analysis reveals that specialization in exports of electronics appears in tandem with a high propensity to import electronics products, particularly components. The paper also proposes a simple synthetic indicator, which captures the essence of the argument without the necessity of looking at the detailed structure of national imports. The possibility that the observed patterns of specialization might suffer from statistical bias because of double (and multiple) counting of components in trade statistics is further investigated in an economic framework. It is shown that technological capabilities explain a certain portion of cross-country differences 
in export specialization in electronics, but the propensity to import electronics components is by far a more relevant explanatory factor. The final section concludes and discusses implications for policy.

\section{The pitfalls of industry-based taxonomies of technological intensity}

A number of taxonomies classifying industries according to technology, science and skills intensity, sources of competitive advantage or general character of innovation processes have been proposed over the years (see Archibugi 2001 and Peneder 2003 for recent overviews). The taxonomies by the OECD and Pavitt (1984) have proved to be particularly influential in the literature.

The OECD taxonomy classifies industries and exports solely by technological intensity. It has been continuously refined since the early 1980s, but perhaps its most sophisticated specification is given by Hatzichronoglou (1997). The sectoral approach combines three indicators: (1) $R \& D$ expenditure in relation to value added, (2) $R \& D$ expenditure in relation to production, and (3) R\&D expenditure embodied in purchased intermediate and investment goods, which reflects technology diffusion in inputs. Accordingly, four groups of industries ranging from high-tech to low-tech are identified at one to four-digit levels of the UN International Standard Industrial Classification (ISIC, rev. 2). The taxonomy of products solely defines high-tech products at three to five-digit levels of the UN Standard International Trade Classification (SITC, rev. 3), which provides a tool for evaluating export specialization. ${ }^{1}$

\footnotetext{
${ }^{1}$ It should be mentioned that the product taxonomy could not be based on actual $R \& D$ intensities of individual products for which data is not available, so that experts have to be consulted with regard to the technology
} 
Pavitt (1984) proposed a typology of sectoral technology trajectories, which classifies industries according to three major factors: (1) sources of technology, (2) nature of the technology produced, and (3) other characteristics of innovating firms, such as size. The resulting classification identifies four groups of industries that are science-based, specialized suppliers, supplier dominated or scale intensive. ${ }^{2}$ Nevertheless, Pavitt and OECD are in broad agreement that certain segments of the economy (and therefore exports) stand out in terms of technological intensity. These are the science-based sector in the former and the high-tech segment in the latter. The empirical identifications of these high technology intensive sectors overlap to a large degree. As the literature has developed, different applications have used slightly different specifications, but it is typical that aerospace, pharmaceuticals and electronics are among those considered as high-tech sectors.

In general terms, classification of individual agents into generic types is a process of reducing heterogeneity (Peneder 2003). On the one hand, some information is lost at each step of aggregation, but on the other hand, some analytical gains can be derived from reducing the vast complexity of individual data. An industry reduces a swarm of firms into an easily understandable narrative, while an industry-based taxonomy further reduces a number of industries into several salient types given their selected attributes. Indeed, the reason that taxonomies are so popular is that they provide even greater simplification of reality than standard industrial classifications, but one should always keep in mind the underlying heterogeneity and apply its reduction carefully.

intensity of some product groups. A certain degree of arbitrariness is embedded in the product taxonomy in contrast to the sectoral approach, which is based on clear-cut quantitative measures.

${ }^{2}$ For a recent research related to the Pavitt's taxonomy see Marsili (2001), Pol, Carroll and Robertson (2002) or Castellacci (2004). 
As soon as a taxonomy is created, moreover, it tends to become detached from the original context and applied repeatedly to various areas and periods. For example, the OECD taxonomy was constructed on the basis of a sample of 22 industries in 10 OECD countries (Hatzichronoglou 1997, pg. 5), which makes it quite problematic to extrapolate attributes of the high-tech category to the context of developing countries, as will be seen below. It is typically assumed in empirical applications of the taxonomy that firms in fields labelled as high-tech are more innovative and employ more skilled workforces without looking at their actual technological competencies and business strategies in the particular location. However, the relative similarity within a taxonomic type and the differences among types are always essential. If these similarities and differences do not apply in the particular context, the taxonomy becomes misleading. As Peneder (2003) puts it, one generally should not use the taxonomic approach only for the purpose of making the analysis more convenient, if more specific data are available in a similar format.

As already noted, similar data for technological capabilities are often not available for developing countries, which makes the quick-fix solution of using the industry-based taxonomies by technological intensity particularly attractive. One has to assume, however, that the similarities and differences between the taxonomic types are primarily industry specific irrespective of the local context. This might be a valid assumption if we compare countries with otherwise broadly similar characteristics, but it might be an unstable basis for an analysis if countries with highly different attributes are under scrutiny. The heterogeneity of industries across countries in particular should not be underestimated in comparisons of economies at greatly different levels of development. Indeed, a new electronic chip design requires different capabilities compared with its manufacturing, testing or even low-skilled assembling into a final product. Although these business activities might fall into the same category of industrial classification, such as electronics, we would get an essentially different 
picture of specialization if looking at them separately. If this is the case, the categorization of electronics as a high-tech industry might be highly misleading in low-cost locations, and application of the taxonomy can hardly be justified by the non-existence of other data.

All of these concerns are even more accentuated by the increasing fragmentation of value chains across national borders. The process of fragmentation means separation of individual phases of production in space, ownership or both (Arndt and Kierzkowski 2001). ${ }^{3}$ Fragmentation is not a new phenomenon by any means. The history of production systems may well be seen as a gradual process of deepening division of labour from local to national and global contexts, and from farms to factories, and ultimately to global production networks. What is unprecedented about the process, however, is the global scale and scope of fragmentation today. The "fragmentability" of value chains has increased substantially as a consequence of advances in technology, while the scope of production networks has reached global dimensions with liberalization of trade and investment in recent decades (and both have been reinforced by the increasing size of international demand).

An important implication of fragmentation is that firms become increasingly specialized in particular segments of value chains within industries, which might make them more similar to firms specialized in corresponding niches of other traditionally perceived industries. Specialization in simple assembly of electronics products is intensive on inputs - such as cheap labour - much more similar to assembly of agricultural machinery and even to the manufacture of garments, compared with the capabilities needed for the development of the next generation of LCD displays. Fragments of value chains from different industries, which

\footnotetext{
${ }^{3}$ Some aspects of the fragmentation process have also been described in the literature as industrial differentiation (Young 1928), vertical disintegration (Rosenberg 1963), integration of trade and disintegration of production (Feenstra 1998), vertical specialization (Hummels et al. 2001), "slicing up the value chain" (Krugman 1995) and simply outsourcing at the firm level (Kogut 1985).
} 
share intensity on similar resources, tend to cluster in countries with relevant endowments. It is the particular fragment of production that clusters locally, not industries with complete value chains. The ultimate effect is that specialization of countries seen through the lenses of the traditional industry and product classifications, let alone the even more aggregated taxonomies, might increasingly fail to capture the underlying reality, especially in comparisons across locations with entirely different endowments.

The flip side is that the deepening fragmentation of value chains allows labour-intensive activities in manufacturing of high-tech products to be carried out in countries that previously had not been able to participate in production of such products. In this respect, the process of fragmentation implies that we should observe increasing exports of high-tech products from the low-cost locations, where the manufacturing segments relocate, whereas the most skillintensive activities, such as research and development, might remain clustered in developed countries. The latter is not tradable - at least not in terms of merchandise trade - so we might even observe a decrease of high-tech exports from the countries at the technological frontier. If this is the case, a comparative analysis of high-tech exports may provide a picture that is actually the opposite of what is going on in reality. We might observe a rapid catching up of developing countries in terms of high-tech exports, while at the same time the actual technology gap may be deepening further.

Still, we often tend to think about specialization in the traditional context of end products and complete value chains. We are accustomed to perceiving exportation of electronics from the United States, Costa Rica and the Philippines as it were the same phenomenon. Does it make sense to think about the export of computers assembled from imported components in the Philippines as high-tech exports? Isn't it the actual technological intensity of business 
activities performed locally, rather than the fact that they happen to be generally classified into the high-tech category, that matters for national specialization? It might well be that we have passed a threshold, when losses from simplifications using industry-based taxonomies become higher than analytical gains from them, particularly for broad cross-country comparisons.

\section{Specialization in high-tech exports: The indicator of what?}

It is well established in the literature that economic development requires structural change, so it is important to analyse structural shifts along the way. It is also rightly argued that moving into manufacturing exports entails greater development opportunities because of economies of scale and scope, export diversification and typically higher skills and technological intensity, compared with exports based on exploitation of natural endowments. Although a broad distinction between primary, resource-based and manufacturing trade is relatively straightforward, it is far more complicated to differentiate technological intensity of trade.

As noted above, it is customary to capture technological intensity of exports by comparing specialization in products perceived as high-tech across countries. Figure 1 provides a comparison for a large group of countries. The share of high-tech products in merchandise exports is plotted on the vertical axis against the intensity of economies in R\&D expenditure on the horizontal axis. The dotted lines show sample averages, which divide the figure into four quadrants with below/above average scores along the two dimensions. The data for trade are based on the World Development Indicators (WDI) dataset from the World Bank, which refers to high-tech exports as products with high R\&D intensity, such as aerospace, 
pharmaceuticals, computers, scientific instruments and electrical machinery. This is in line with the definition of the OECD taxonomy and is fairly close to exports of industries generally viewed as science-based, in Pavitt's taxonomy. The data for R\&D expenditure are drawn from various sources, including OECD (2005), UNESCO (2005), RICYT (2005) and national sources. The data should be broadly similar to definitions given by the OECD Frascati Manual.

Figure 1: High-tech exports and R\&D expenditure, average over 2001-2003

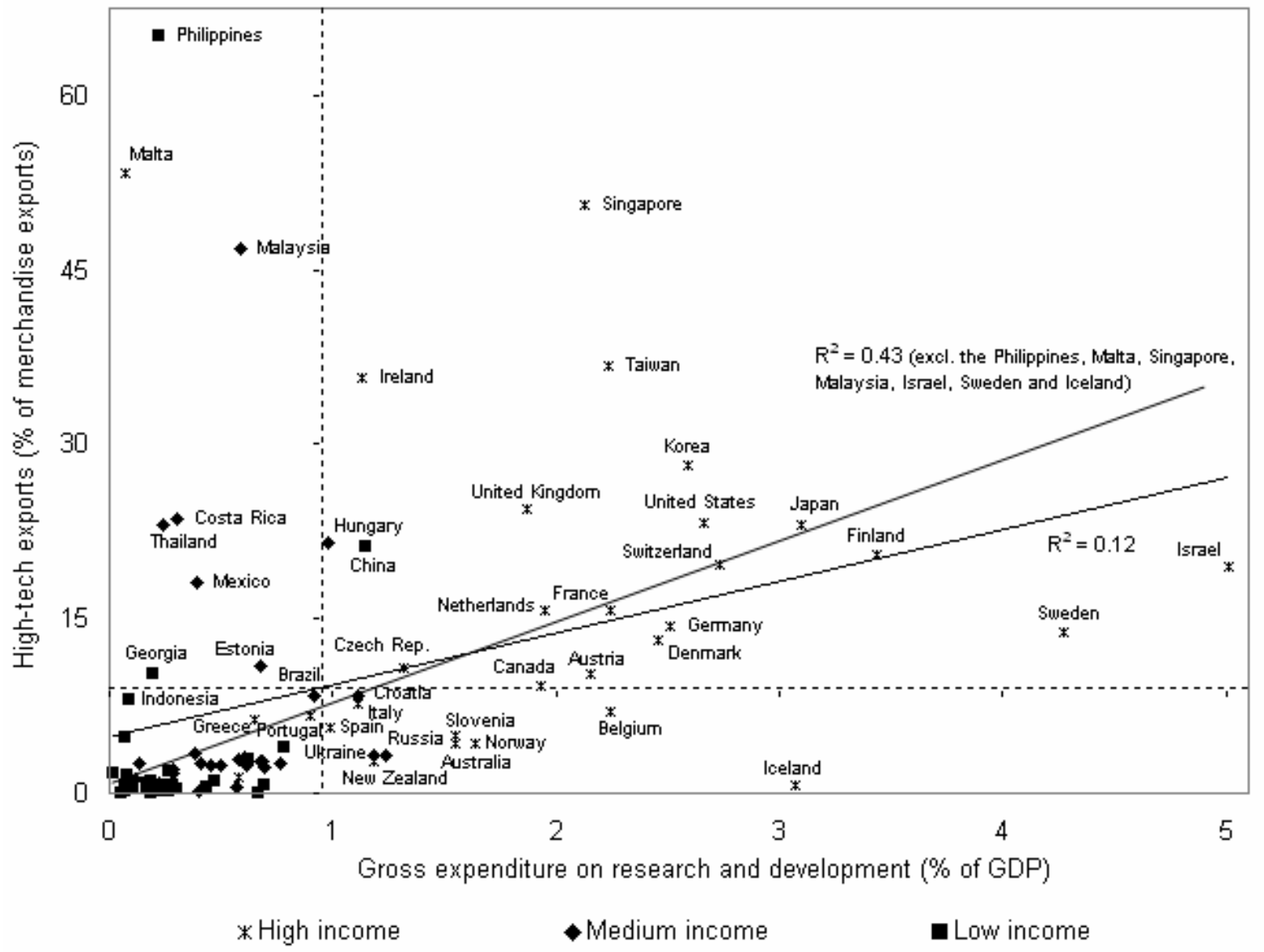

Note: The income groups given by GDP per capita (PPP, constant 2000 USD) are as follows: high income: more than 15,000; medium income: between 5,000 and 15,000; low income: less than 5,000. R\&D expenditure in Malta was estimated according to data for R\&D employment.

Source: World Bank (2005), OECD (2005), UNESCO (2005), RICYT (2005) and national sources. 
A majority of countries maintain a below-average share of high-tech exports, which means that they are not specialized in exporting these products. Most low-income countries report negligible high-tech exports, although specialization in high-tech exports is by no means a privilege of the most technologically advanced countries. Striking is the fact that the country specializing the most in high-tech exports is the Philippines, where roughly $65 \%$ of exports fall into the high-tech category. Other outliers include Malta, Singapore, Malaysia, Taiwan and Ireland, where high-tech products account for more than a third of exports. A handful of typical examples of latecomer countries, such as Korea, China, Thailand, Costa Rica, Mexico and Hungary also perform quite well in the high-tech area. What does it mean? What does it tell us? Looking solely at the specialization in high-tech exports, one could easily conclude that many developing countries have been extremely successful in catching up technologically and have even overtaken the United States, Japan and the EU in terms of the technological intensity of their economies.

A look at the horizontal axis reveals the lingering divide between the developed and developing countries in terms of indigenous technological capabilities. Specialization in hightech exports does not match the intensity of the economy in R\&D expenditure in many areas, particularly in the examples of high-tech exporters from latecomer countries given above. Hence the fundamentals of specialization patterns of these countries are probably not based on sophisticated technological capabilities. The figure confirms the expectation that production systems in the high-tech fields became internationally fragmented to the extent that countries can export large amounts of high-tech products while actually mastering very limited technological capabilities themselves. The overall correspondence between the intensity on high-tech exports and $R \& D$ spending given by $R^{2}$ comes out at 0.12 , suggesting that the indicators share only about one tenth of cross-country differences. If we omit the most 
extreme outliers from the comparison (the Philippines, Malta, Singapore, Malaysia, Israel, Sweden and Iceland), however, $\mathrm{R}^{2}$ edges up to 0.43 , which confirms that the indicators are associated to a certain extent. Still there are other factors with much more explanatory power as will be seen below.

The disparity is most striking in the Philippines, Malta, Malaysia, which have more than $45 \%$ of exports in the high-tech fields, and to a lesser extent in Costa Rica, Mexico and Thailand, with around $20 \%$ of high-tech exports, but their spending on R\&D is well below $1 \%$ of GDP. In general, the East Asian region clearly emerges as an important cluster for the manufacturing of high-tech products, but there seems to be a fairly strong divide in localization of related technological capabilities in the "first tier" of the newly industrialized countries and the rest of the region. A group of high-income Asian countries, namely Singapore, Taiwan, Korea and Japan, is among the top 15 countries in both specialization in high-tech exports and R\&D intensity, while the others fall well behind in technological capabilities. As a consequence of its sheer size and unique development trajectory, China is arguably a special case in this context. In terms of R\&D intensity, China has already overtaken some of the high-income countries such as Ireland and some southern European countries. Regional differences between gravitational centres of business activity and other mainly rural areas suggest that some Chinese regions probably maintain an R\&D intensity substantially above the national average and even closer to that of other developed countries. ${ }^{4}$

As suggested, the phenomenon behind the contrast between specialization in high-tech exports and indigenous R\&D capabilities is the increasing fragmentation of value chains,

\footnotetext{
${ }^{4}$ According to the OECD (2005), R\&D expenditure in terms of GDP is reported at 1.2\% in China in 2002, which should be based on methodology comparable with other OECD countries. The R\&D intensity is estimated to range from $0.60 \%$ to $0.83 \%$ over the $1990 \mathrm{~s}$, but OECD notes that these earlier figures are based on underestimated data.
} 
particularly the separation of technological development from related manufacturing activities in this context. The available empirical evidence seems to confirm the fact that technologically intensive activities are sticky and remain localized in the home countries of large multinational corporations (Patel and Pavitt 1991, Pavitt and Patel 1999, Verspagen and Schoenmakers 2003). Foreign direct investment in R\&D is increasing worldwide, but it is highly concentrated among developed countries (Le Bas and Sierra 2002). It is therefore not surprising that $\mathrm{R} \& \mathrm{D}$ intensity remains rather low in developing countries despite the surge in high-tech exports, as they attract mainly manufacturing-based fragments of global production systems, while the technology-intensive fragments remain concentrated elsewhere.

Srholec (2006) looks directly at R\&D intensity of the high-tech sectors. It is confirmed that some OECD members with a relatively low income compared with the frontier countries, such as Mexico, Poland, Slovakia, Hungary and the Czech Republic, maintain vastly lower R\&D intensity in high-tech electronics compared with the OECD threshold that draws a cutoff point between high-tech and the rest of manufacturing (around $20 \%$ of R\&D in relation to value added according to OECD 2003, p. 156). It makes it truly problematic to use any hightech labels in the context of these countries. A look at the aggregate data suggests that it is plausible that the relevant industries also remain well below the OECD threshold in most of the other prominent high-tech exporters, which are well behind the technology frontier.

Despite their limited development of local technological capabilities, some might argue that high-tech industries can still contribute to development because of greater potential for spillover effects in the economy. Relatively little is known, however, about the geographical reach of knowledge spillovers. As the literature suggests, spillovers are often rather local because knowledge is sticky in nature, with a good part of it being tacit. One needs 
appropriate absorptive capacity to benefit from spillovers, because technology is not only costly to produce, but also costly to transfer; and of course, the more sophisticated technology becomes, the more difficult it is to transfer it in space. Therefore, as R\&D spillovers are bounded in space - by national or other relevant borders - what ultimately matters is the actual R\&D intensity of activities undertaken locally rather than the technological intensity of an industry in general.

A closer look at the trade in high-tech products reveals that it is largely concentrated in a limited range of product groups. Figure 2 compares specialization in high-tech exports and in electronics. Data for the latter have been obtained from the United Nations (2005) and cover trade in the following products: office, accounting and computing machinery (75); radio, television and communications equipment (76), electrical machinery (77) and medical, precision and optical instruments $(87,881,884$ and 885$)$ - all codes according to SITC, rev. 3. It is apparent that electronics accounts for the bulk of high-tech exports in most countries. Therefore, in the following sections, we focus narrowly on the analysis of trade in electronics as a broad representation of high-tech exports. ${ }^{5}$

\footnotetext{
${ }^{5}$ Given the same scale on both axes, the figure actually suggests that the share of electronics is in many cases higher than the share of high-tech products reported in the WDI database, with the most extreme example being Hong Kong. It is not entirely clear which electronics products have not been included in the high-tech category in the WDI database, nor it is obvious from a closer inspection of the data for Hong Kong which particular products cause the difference. Srholec (2006) strictly follows the very detailed product-based OECD taxonomy of exports defined by Hatzichronoglou (1997), which shows that electronics had a joint share of nearly $80 \%$ in total world trade in high-tech products in 2000. The study also confirmed that the vast majority of high-tech exports from developing countries was concentrated in electronics.
} 
Figure 2: Domination of high-tech exports by electronics in 2003

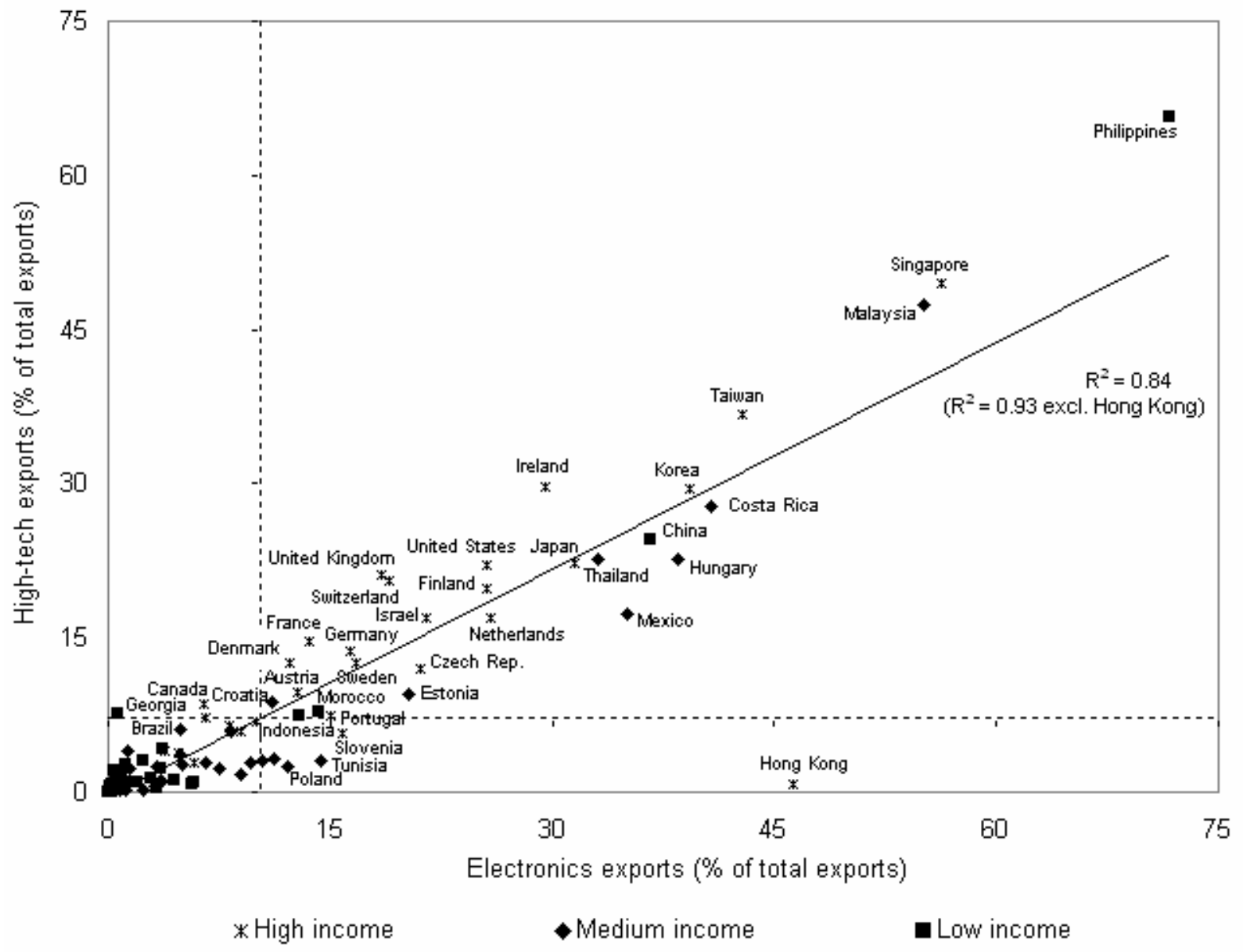

Note: The income groups given by GDP per capita (PPP, constant 2000 USD) are as follows: high income: more than 15,000; medium income: between 5,000 and 15,000; low income: less than 5,000.

Source: World Bank (2005) and United Nations (2005). 


\section{The effect of fragmentation on trade in electronics}

How could a developing country turn out to be a top exporter of electronics despite having very limited technological capabilities? Could it be one of the peculiar outcomes of high openness to trade, foreign direct investment and globalization in general? In order to throw some new light upon these questions, we look more closely at the role of the deepening fragmentation by examining intra-product trade in electronics. The dispersion of the various fragments of production systems mirrors in flows of inputs (production factors and intermediate inputs such as parts and components) between countries, which makes it possible to trace fragmentation in trade statistics.

Following Kaminski and Ng (2001), Yeats (2001) and Lall et al. (2004), we establish a distinction between trade in final electronics products and trade in their components. Instead of using their rather arbitrary classification of products into these two groups, however, we use the Broad Economic Categories (BEC, rev. 3) classification officially defined by the United Nations, which separates trade in final products from intermediate inputs for the purpose of national accounts. ${ }^{6}$ Given the availability of relevant data, the analysis provides evidence for a sample of 111 countries in 2003 (see Appendix 1 for overview of the sample). The data are based on the UN Comtrade database (United Nations 2005) with the only exception being Taiwan, for which fully comparable data are available from the OECD International Trade by Commodity Statistics.

\footnotetext{
${ }^{6}$ The classification used by Kaminski and $\mathrm{Ng}$ (2001), Yeats (2001) and Lall et al. (2004) is based on SITC (rev. 2) for selected products. The BEC classification separates trade in final products from components for most manufacturing products at a very detailed (4-5 digit) level of SITC (rev. 3) and (6-digit) level of HS (1996 or 2002) classifications. The definition based on SITC (rev. 3) is used in this paper.
} 
It is essential to realize that trade statistics do not measure domestic value added embodied in national exports, but only gross value (sales or turnover) from exports, which creates a direct link between the exports and imports of a country (Krugman, 1995). The basic idea is that electronics components - as intermediate inputs - can be imported for the assembly of final products to serve domestic and foreign markets or for processing in the country to be reexported, still as components (such as inward-outward processing trade). If a country imports components, their full value might be also fully mirrored in export "sales" of the country irrespective of (a possibly low) value actually having been added in the country. This has two direct consequences: (i) the value of world trade is inflated by components repeatedly crossing national borders, of which the full value is counted multiple times in trade along the route, and (ii) a direct link between the value (and structure) of national imports and exports is created with countries involved in the intra-product trade appearing to be specialized in certain products even if value added domestically to the exports is fairly low. As the degree of fragmentation and hence the inflation of trade statistics is unevenly distributed across industries and countries, this effect biases the structure of world trade and comparisons of national specialization.

Figure 3 provides first indications of the possible impact of fragmentation by plotting the share of electronics in exports against the share of the same products in imports, both expressed in terms of total trade (sum of exports and imports) in order to display the indicators on the same scale. It comes out that high specialization in electronics exports goes firmly in tandem with an enormous propensity to import products in the same category. The link is particularly strong for the group of top electronics exporters displayed in the upper part of the figure. Given the same units and scales on both axes, we can also directly observe the trade balance in electronics, which is given by the dotted line. Countries in the upper left 
segment of the figure have a trade surplus, while countries in the lower right area maintain a trade deficit. The figure reveals that despite the high import propensity, none of the countries that are highly specialized in electronics suffers from a trade deficit in these products, although the trade is essentially balanced in some, such as Hong Kong, China and the Netherlands. Of course, the surplus is certainly a positive outcome for the top electronics exporters; yet one would probably expect much higher surpluses in many of them given the importance of electronics in their export specializations. Unfortunately, we cannot conclude much from the size of the surplus regarding the amount of domestic value added per employee to the exports, which would indicate the underlying technological intensity of the local export base.

Figure 4 reveals the relative importance of final electronics products and their components in imports. A large share of components in imports suggests high involvement of a country in global production systems and indicates possible bias in export specialization if the imported components tend to be mirrored in value of exports again. The difference along these two lines among countries specializing in exports of electronics on the one hand, and East Asia compared with the rest of the world on the other hand, clearly confirms that the divide matters at least from an analytical point of view. The share of final electronics products appears in a relatively narrow range in most countries, with a maximum of only $16.3 \%$ in Hong Kong, while the share of electronics components accounts for more than $18 \%$ in 12 other countries and edges up to $35.0 \%$ in Singapore, $44.9 \%$ in Malaysia and $47.3 \%$ in the Philippines. Most of the latter are economies well below the technological frontier and/or from countries East 
Figure 3: Exports and imports of electronics in 2003

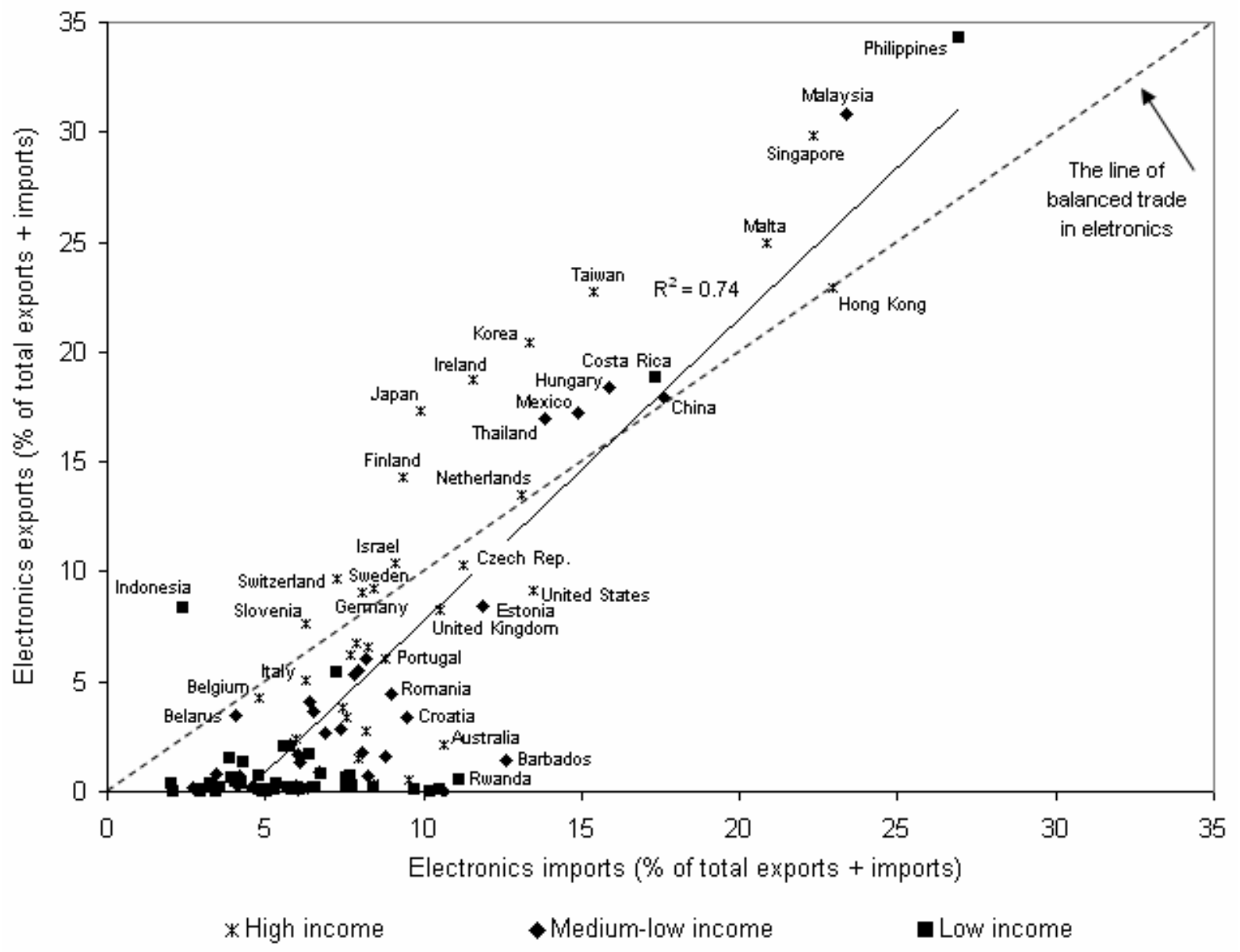

Note: The income groups given by GDP per capita (PPP, constant 2000 USD) are as follows: high income: more than 15,000; medium income: between 5,000 and 15,000; low income: less than 5,000.

Source: Own computations based on the United Nations (2005).

Asia. On the other hand, the United States, Japan and all of the EU members (except Ireland, Malta and Hungary) maintain a share of electronics components not very different from the average, which makes it approximately equal to the share of final electronics products in these countries. It is not surprising to see predominantly lower income countries with high imports of electronics components because processing of components or their assembly into final products is obviously intensive on endowments other than technological capabilities. The main exceptions are Singapore, Taiwan and Korea with high components imports as well as relatively developed technological capabilities, which probably points to their rather special role as hubs in the East Asian production networks. 
Figure 4: Imports of components and final products in 2003

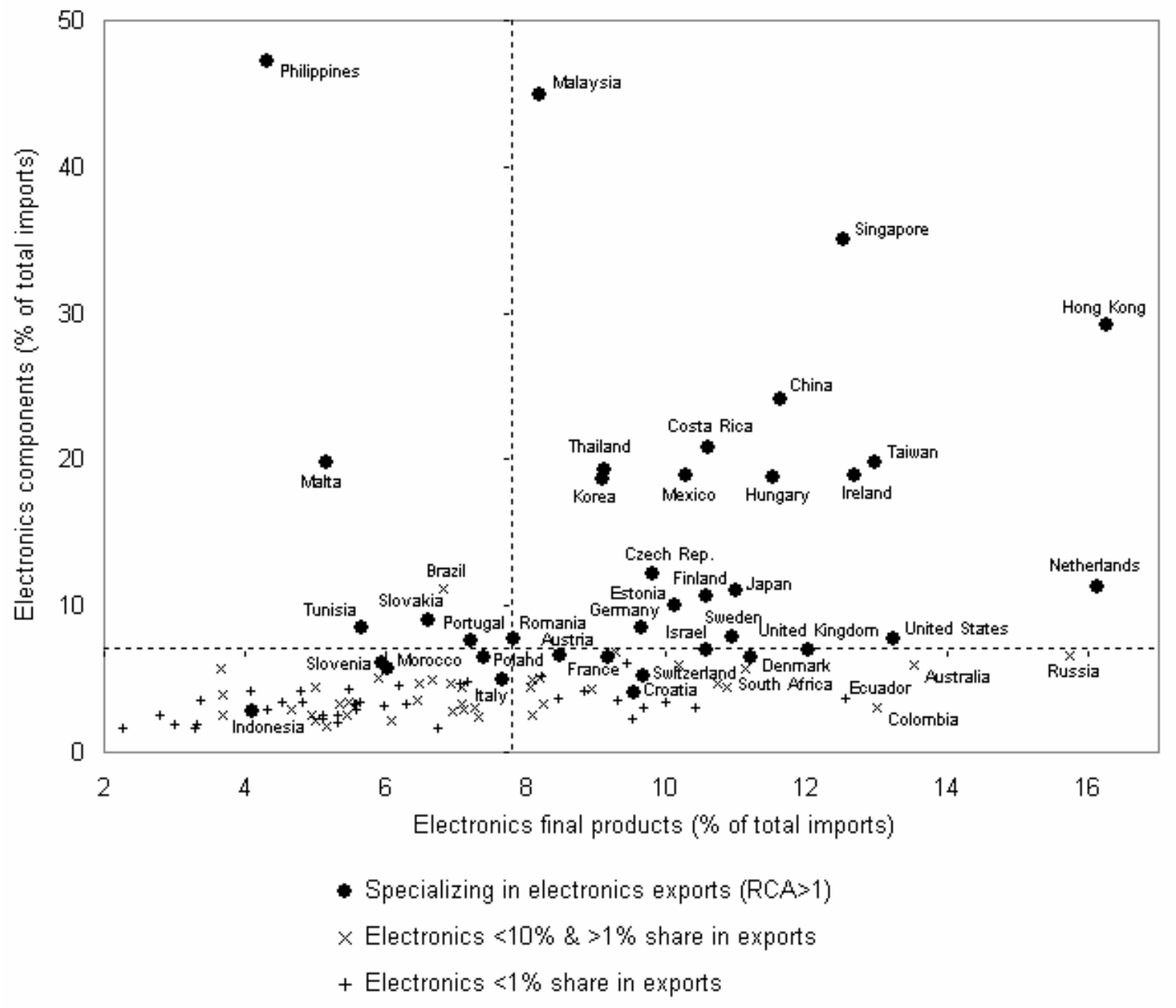

Note: RCA is the index of revealed comparative advantage - see chapter 4 for formal definition. Source: Own computations based on the United Nations (2005).

Footprints of production networks orchestrated by the leading multinational corporations in electronics can be traced in the trade of many countries. ${ }^{7}$ It is this segment of trade where intra-product trade within value chains of products widely overlaps with intra-firm trade between subsidiaries under the ownership umbrella of a single multinational corporation. Localization of manufacturing plants of the multinational corporations leaves strong patterns in trade of latecomer countries. For example, General Electric maintains manufacturing

\footnotetext{
${ }^{7}$ The global governance of value chains by multinational corporations has been thoroughly examined in the business literature (see Kogut 1985, Ernst and Kim 2002 or Gereffi, Humphrey and Sturgeon 2005 and other references therein).
} 
facilities in approximately 40 countries; the leading chipmaker, Intel, has large manufacturing plants in the Philippines, Malaysia, China, Ireland, Israel, Costa Rica and Mexico; the footprints of IBM can be found in Singapore, China, Thailand, Mexico, Ireland and Hungary; Siemens maintains major investment projects in China, India, Brazil and the Czech Republic; while the European semiconductor manufacturer ST Microelectronics dominates the electronics trade of the small Maltese economy. A similar pattern appears in the global spread of production networks of electronics contractual manufacturers such as Solectron, Flextronics or Celestica (Lüethje 2001). It is probably localization of these factories that accounts for a substantial part of both the electronics exports and imports of many developing countries.

It is evident from the analysis that the distinctive feature of countries with a generally high share of electronics in imports (and consequently in exports) is a particularly high propensity to import electronics components. Perhaps nothing could be more telling than the fact that specialization in electronics exports is highly correlated to imports of electronics components $\left(\mathrm{R}^{2}=0.85\right)$, whereas there seems to be no relation between electronics exports and imports of final electronics products $\left(\mathrm{R}^{2}=0.04\right)$ when expressed in terms of total trade. In other words, the findings suggest that cross-country variance in propensity to import electronics is driven by imports of components. 


\section{The factors behind high-tech exports: regression analysis}

The descriptive analysis has suggested that specialization in high-tech exports appears in tandem with technological capabilities in countries close to the technological frontier, but there is also a group of mostly latecomer countries with high performance in high-tech exports, particularly in electronics, that is largely based on other than technological comparative advantages. A distinctive feature of the latter group is their high propensity to import electronics components, which reflects their alignment with global production networks, but also raises some doubts regarding the actual basis for their performance in electronics exports.

A natural next step is to examine the relative relevance of the factors outlined above in an econometric framework. The dependent variable is specialization in electronics exports, which is regressed against the level of indigenous technological capabilities and indicators reflecting the propensity to import electronics. Following the analysis of intra-product trade, we distinguish between imports of electronics final products and electronics components. All of the trade-based indicators are expressed in terms of total trade (sum of exports and imports) to maintain them on the same scale. The aim of the regression analysis is to assess relative explanatory power of technology capabilities as compared to the propensity to intra-product imports for explaining specialization in exports of electronics.

Data on R\&D expenditure are available only for 83 countries in the sample. In order to refrain from estimating the key explanatory variable for a relatively large number of countries, we construct alternative measure of technological capabilities based on indicators with broader cross-country coverage: number of ICT patents at the USPTO per capita, number of personal 
computers per capita and gross tertiary enrolment. Some limited data for the latter two indicators remained to be estimated. ${ }^{8}$ The choice of the indicators is aimed at accounting for factors related directly to technological capabilities in electronics, which are represented by the patenting records in the relevant areas and the diffusion of computers in the economy, as well as for some aspect of skills endowment represented by higher education. Since the variables are highly correlated, we have used factor analysis to construct a single composite indicator of technological capabilities. ${ }^{9}$ A brief look at the correlation table given in Appendix 2 reveals that the composite is also highly correlated to intensity of $R \& D$ expenditure (in the limited sample for which the $R \& D$ data are available), which confirms its relevance in this context.

Some caveats in the measures of intra-product imports should be acknowledged at this point. We do not really know whether the imported components are directed into export-oriented production or manufactured into products for a domestic market. If the latter is the case, no loop between imports and exports occurs, with obviously no influence on exports specialization. For example, China specializes in exports of electronics and imports large amounts of electronics components, but also has a large and expanding domestic market, where some of the products manufactured from the imported components are marketed. The regression analysis allows us to address at least partly the caveat by controlling for the size of the domestic market through inclusion of population (in logs) in the estimate. It might also

\footnotetext{
${ }^{8}$ The indicators are used in the form of three-year averages over the period 2001-2003 in order to increase coverage across countries and to limit the influence of fluctuations occurring in specific years. We used the regression-based impute procedure in Stata 9 to fill the missing values for personal computers in five countries and for tertiary enrolment in four countries (the imputation was based on the other technology variables). The data for personal computers and gross enrolments in tertiary education have been drawn from the World Bank (2005) and the data for ICT patents from OECD Patent Database - for definition of the ICT-related patents, see OECD (2003, p. 26). The number of ICT patents for the United States has been adjusted following the approach by Archibugi and Coco (2004, p. 633) to account for a possible home base advantage.

${ }^{9}$ The factor analysis (principal-component method) identified only a single factor with eigenvalue above unity (eigenvalue $=2.21,73.6 \%$ of variability explained) with the following factor loadings of the variables: ICT patents per capita $=0.82$, computers per capita $=0.93$ and gross tertiary enrolment $=0.83$.
} 
have been relevant to include differences in purchasing power of the domestic market (GDP per capita in PPP), but this is already picked up by the composite of technological capabilities because these indicators are highly correlated to $\left(\mathrm{R}^{2}=0.75\right)$.

Table 1 gives the regression results. The first column provides results of an ordinary least square estimate. All of the variables come out as significant explanatory factors. It is confirmed that technological capabilities matter for specialization in electronics exports, although the propensity to import electronics components explains even more. The magnitude of the coefficient for the latter is roughly three times greater than that for the technological capabilities, which highlights the fact that the bulk of cross-country differences in electronics exports should rather be attributed to intra-product imports. ${ }^{10}$ The overall explanatory power is very high - the estimate explains around $92 \%$ of cross-country differences in specialization in electronics exports.

The effect of the other two explanatory variables seems to be relatively marginal, but the significantly negative sign of the propensity to import final electronics products deserves some explanation. It is put forward in the so-called "new trade theories" that countries simultaneously export and import products from the same industries because of product

\footnotetext{
${ }^{10}$ All of the variables have been standardized (deducting mean and dividing by standard deviation) before running the regressions, which essentially implies that beta coefficients of the estimated parameters are reported. Since the variables are on the same scale, the beta coefficients allow for a direct comparison of the coefficient's magnitude across variables. Another effect of the standardization is that sample average is equal to zero, which implies that by definition, the constant term equals zero as well (except the robust least squares estimate, where the observations are given different weights). All other reported regression statistics remain intact.
} 
Table 1: Regression results

\begin{tabular}{|l|ccc|}
\hline Method of estimate: & $\begin{array}{c}\text { Ordinary least } \\
\text { squares }\end{array}$ & $\begin{array}{c}\text { Robust least } \\
\text { squares }\end{array}$ & $\begin{array}{c}\text { Two-stage least } \\
\text { squares }\end{array}$ \\
\hline Constant &.. & -0.001 &.. \\
Size (population in logs) &.. & $(0.04)$ &.. \\
& $0.08^{* *}$ & $0.06^{* *}$ & $0.07^{* *}$ \\
Technological capabilities & $(2.32)$ & $(2.50)$ & $(2.24)$ \\
& $0.29^{* * *}$ & $0.29^{* * *}$ & $0.25^{* * *}$ \\
Imports of components & $(7.96)$ & $(11.64)$ & $(3.92)$ \\
& $0.87^{* * *}$ & $0.89^{* * *}$ & $0.93^{* * *}$ \\
Imports of final products & $(20.26)$ & $(38.21)$ & $(7.29)$ \\
& $-0.08^{* * *}$ & $-0.08^{* * *}$ & $-0.15^{* * *}$ \\
\hline F & $(2.71)$ & $(3.15)$ & $(2.74)$ \\
R2 & 172.37 & 481.26 & 88.63 \\
Number of observations & 0.92 &.. & 0.91 \\
\hline
\end{tabular}

Note: The dependent variable is exports of electronics - all of the trade-based indicators are expressed in terms of total trade (sum of exports and imports) of a country in order to adjust for size differences and to retain them on the same scale. The absolute value of robust t-statistics is given in parentheses; ${ }^{*}, * *, * * *$ denote significance at the 10, 5 and 1 per cent levels, respectively. An overview of instruments for the two-stage least squares estimate is given in Appendix 3. Standardized variables are used in the estimates (beta values reported, which implies that the coefficient's magnitude is directly comparable across variables, and the constant term is equal to zero by definition).

differentiation (Helpman and Krugman 1985, Krugman 1995, Lee and Lloyd 2002), which has been dubbed intra-industry trade. However, as emphasized by Arndt and Kierzkowski (2001), even though the literature on intra-industry trade should naturally examine trade in components, it tends to focus mostly on trade in varieties of final products. ${ }^{11}$ Our analysis clearly reveals that it is the import of components in particular that goes in tandem with exports of products from the same industry, at least as far as electronics is concerned. In fact, imports of final products are even negatively associated with exports of the same products.

\footnotetext{
${ }^{11}$ It should be mentioned that there is some overlap between the concepts of intra-industry and intra-product trade (and also intra-firm trade as already noted above). If vertical and horizontal differentiation of trade within an industry is distinguished, the former can be dubbed vertical intra-industry and the latter horizontal intraindustry trade (Greenaway, Hine and Milner 1995). The vertically differentiated intra-industry exchange overlaps with intra-product trade between firms in the same industry, although the latter concept covers much broader phenomenon - components originating from a certain industry can be used as intermediate inputs into wide range of other industries, which is particularly the case for generic components. From this perspective, the regression analysis particularly takes into account the vertical intra-industry segment of the broader intra-product trade in electronics. For more detailed discussion along these lines, including formal modeling, see for example Feenstra (1998), Jones (2000) and Arndt and Kierzkowski (2001).
} 
The regression results can be influenced by the presence of outliers in the sample. To check for possible bias, we performed robust regression - iteratively reweighted least squares which assigns a certain weight to each observation, with lower weights given to outliers. Not much change occurred in the robust estimate. The magnitude of coefficients turns out to be very similar, while the significance of the explanatory variables and the model improved. Hence, the results do not seem to be driven by outliers.

Moreover, reverse causality from the specialization in electronics exports to the technological capabilities as well as patterns of imports cannot be excluded, so we account for impact of the potentially endogeneity of these variables by performing a two-stage least squares estimate. The composite of technological capabilities and the propensity to import components and final products were instrumented by a battery of exogenous factors given by history, geography and culture, which proved to be valid instruments (not correlated to residuals of the first stage regression - see Appendix 3 for an overview of the instruments). The results are reassuring. The main difference is in the coefficient for imports of final products, for which the magnitude doubled, while the estimated coefficients for the other variables are not affected. ${ }^{12}$ It is further confirmation of a rather substitution relation between imports of final products and exports in the same industry, while the opposite seems to be the case for import of components. If a country has a productive capacity in electronics, part of it goes to exports and some of it substitutes for imports of final products

\footnotetext{
${ }^{12}$ A Durbin-Wu-Hausman test of endogeneity confirms that the propensity to import final products appears to be endogenous at the $15 \%$ level (the other suspected variables do not seem to be endogenous at the $20 \%$ level). The test is performed by first regressing each potentially endogenous explanatory variable on all exogenous variables, including instruments, and then adding residuals from these regressions in the second regression. If some of the residuals come out as significant in the second regression, the endogeneity of the variable is detected. For further details see Wooldridge (2002, pp 118-122).
} 


\section{Conclusions}

Although the theoretical argument about the role of specialization in technologically intensive activities for development is perhaps more relevant than ever in the context of the "globalizing learning economy", we should use taxonomies to gauge empirically the technological intensity of exports with caution. Our analysis suggests that the share of hightech products in exports is not necessarily associated with indigenous technological capabilities. We show that high specialization of certain - particularly developing - countries in electronics exports is to a large extent a reflection of the rapid dispersion of global production networks across national borders, which inflates trade statistics with these products. It is right to issue a warning for those tempted to apply the industry-based taxonomies in broad cross-country comparative studies, particularly for comparing countries at largely different levels of development.

Mani (2000) has already pointed to a possible difference between specialization in exports of electronics parts and exports of final products. But looking solely at the structure of exports, Mani finds little support for the "statistical illusion" hypothesis regarding high-tech exports from developing countries. Being aware of the possible effect of fragmentation on export specialization, Lall et al. (2004) also seek to refine the taxonomic approach by using the distinction between finished products and their components. However, they found it difficult to capture the fragmentation effect in electronics and automotive industries empirically. The main contribution of this paper is to show that the distinction between trade in final products and their components truly matters for cross-country differences in electronics exports. It comes out that the key to capturing the effects of fragmentation is to take into account the structure of the import side, rather than to refine the taxonomies by deeper analyses of exports. 
Our findings suggest that developing countries typically attract manufacturing-based fragments of global production networks in electronics, while technology-intensive activities remain concentrated elsewhere. Even if a country exports large amounts of high-tech products, it can remain specialized in low-tech and low-skill fragments of the particular value chain while actually mastering very limited technological capabilities. The fundamentals of the specialization patterns of these countries, in terms of actual technological intensity of production fragments localized in the country, might not have changed so much. Contrary to some popular beliefs, it comes out that upgrading of indigenous technological capabilities is a more complex process than a first look at the outstanding performance of some latecomer countries in high-tech exports might suggest.

Nevertheless, the conventional wisdom in the literature, and particularly among policy makers, is that increasing specialization in high-tech exports is highly desirable for development. A typical industrial policy is focused on providing incentives to attract investment into selected segments of the economy identified primarily in terms of industries, such as into high-tech sectors. It is often taken for granted that a complete value chain of the industry will be localized in the country, without sufficiently considering the actual content of activities that the investor is going to develop locally. What matters for technological catching up in the world of fragmented production systems, however, is not whether the investor happens to fall into certain bracket in terms of the standard industrial classification, but whether the project is truly going to create high skill-intensive jobs in a particular location. Industrial policies should be directly targeted at specific business activities of "strategic" importance for technological catching rather than on specific industries and orchestrated with innovation and education policies to capitalize fully on the potential for catching up. 
A major limitation of the study is the cross-sectional nature of the analysis, which prevents us from capturing dynamic effects related to increasing alignment of countries to the global production networks. As suggested in the literature, participation in electronics production networks requires learning and should be accompanied by technological upgrading in developing countries (Ernst 2001, Ernst and Kim 2002, Hobday 2003). It is important to realize, on the other hand, that the deeper fragmentation - increasing division of labour implies deeper specialization of firms as well as regions and countries in particular niches of the fragmented value chains, which makes a lock-in situation in such fragments more likely. A country with initially underdeveloped technological capabilities might in fact risk a further reinforcing of its comparative advantage at the low-cost edge of globalized value chains. It is an important challenge for future research to illuminate the dynamic effects accompanied to increasing fragmentation on economic development.

It should be further noted that there are some pitfalls in the intra-product trade indicators as well. As already noted above, the trade data do not allow us to determine whether the imported components are going to be used in export or domestic-oriented production, and we do not really know whether a particular component is going to be directed into the same or other industries. Hence, the results indicate the upper boundary of statistical bias because of fragmentation and should therefore be interpreted with caution. A high priority in future research should be given to finding better indicators that can further improve our understanding of the effects of fragmentation on trade and other statistics.

The effect of fragmentation is fairly obvious in electronics, but more research is needed to find out the extent to which other industries are also affected. It might well be that the paper 
points to a general problem in comparative analyses based on standard industrial and trade statistics, at least as far as manufacturing is concerned. Our results suggest that it is generally preferable to use direct evidence from firm-level (or even establishment-level) data in economic analyses instead of aggregated data by industry if relevant micro datasets are available for research purposes (see chapters 5 and 6 of this thesis). In particular, the empirical identification of various theoretical typologies should be context specific using their actually observed attributes in the particular country in question rather than applying the general industry-based taxonomies based on data from elsewhere.

Although the industry-identified taxonomies appear to be problematic for use in broad crosscountry comparative analyses, they still do not lack merit in empirical research, even in the context of developing countries. It may actually be welcome that an industry-based taxonomy reflects certain attributes of industries irrespective of the local context. The general attributes of the taxonomic types provide variables exogenous to the particular location, which can be used to control for purely industry-specific factors (for example, see chapter 5 of this thesis). The contrast between the technological intensity of an industry worldwide and that in a particular location might also be interpreted as a potential for technological catching up - an opportunity for development driven by the high-tech industries realized elsewhere, which fails to be fully exploited in the particular latecomer country. 


\section{References}

Alesina, A., Devleeschauwer, A., Easterly, W., Kurlat, S., Wacziarg, R. (2003)

Fractionalization. Journal of Economic Growth, 8, pp. 155-194.

Archibugi, D. (2001) Pavitt's taxonomy sixteen years on: A review article. Economics of Innovation and New Technology, 10, pp. 415-425.

Archibugi, D. and Coco, A. (2004) A new indicator of technological capabilities for developed and developing countries (ArCo). World Development, 32, pp. 629-654.

Arndt, S. W., Kierzkowski, H., eds. (2001) Fragmentation, New Production Patterns in the World Economy. Oxford, Oxford University Press.

Castellacci, F. (2004) How does innovation differ across sectors in Europe? Evidence from the CIS-SIEPI database. Proceedings from the Second Globelics Conference on Innovation Systems and Development, Emerging Opportunities and Challenges, Beijing, Tsinghua University, October 2004.

Dalum, B., Laursen, K. and Verspagen, B. (1999) Does specialization matter for growth? Industrial and Corporate Change, 8, pp. 267-288.

Dosi, G., Freeman, C., Nelson, R. R., Silverberg, G. and Soete, L., eds. (1988) Technical Change and Economic Theory. London, Pinter.

Ernst, D. (2001) Moving Beyond the Commodity Trap? Trade Adjustment and Industrial Upgrading in East Asia's Electronics Industry. Honolulu, East-West Center, Working Paper No. 10.

Ernst, D. and Kim, L. (2002) Global production networks, knowledge diffusion, and local capability formation. Research Policy, 31, pp. 1417-1429.

Fagerberg, J. (1988) International competitiveness. Economic Journal, 98, pp. 355-374.

Fagerberg, J. (1997) Competitiveness, scale and R\&D. In: Fagerberg, J., Hansson, P., Lundberg, L. and Melchior, A.: Technology and International Trade. Cheltenham, Edward Elgar, pp. 38-54.

Fagerberg, J., Guerrieri, P. and Verspagen, B., eds. (1999) The Economic Challenge for Europe. Adapting to Innovation Based Growth. Cheltenham, Edward Elgar.

Fagerberg, J. (2002) Technology, Growth and Competitiveness, Selected Essays. Cheltenham, Edward Elgar.

Fagerberg, J. and Srholec, M. (2004) Structural changes in international trade: Cause, impact and response. Revue Economique, 55, pp. 1071-1097.

Fearon, J. D. and Laitin, D. D. (2003) Ethnicity, insurgency, and civil war. American Political Science Review, 97, pp. 75-90.

Feenstra, R. (1998) Integration of trade and disintegration of production in the global economy. Journal of Economic Perspectives, 12, pp. 31-50.

Gallup, J. L., Sachs, J. D. and Mellinger, A. (1999) Geography and Economic Development, Harvard University, CID Working Paper no. 1/1999.

Gereffi, G., Humphrey, J. and Sturgeon, T. (2005) The governance of global value chains. Review of International Political Economy, 12, pp. 105-128.

Greenaway, D., Hine, R. and Milner, C. (1995) Vertical and horizontal intra-industry trade: A cross-industry analysis for the United Kingdom. The Economic Journal, 105, pp. 1505-18. 
Guerrieri, P. and Milana, C. (1995) Changes and trends in the world trade in high-technology products. Cambridge Journal of Economics, 19, pp. 225-242.

Hatzichronoglou, T. (1997) Revision of the High-technology Sector and Product Classification. Paris, OECD, STI Working Paper 1997/2.

Helpman, E. and Krugman, P. R. (1985) Market Structure and Foreign Trade. Cambridge, Cambridge University Press.

Hobday, M. (2003) Innovation in Asian Industrialization: A Gerschenkronian Perspective. Oxford Development Studies, 31, pp. 293-314.

Hummels, D., Ishii, J. and Yi, K. M. (2001) The nature and growth of vertical specialization in world trade. Journal of International Economics, 54, pp. 75-96.

IMD (2005) The World Competitiveness Yearbook 2005. Lausanne, IMD-World Competitiveness Center.

Jones, R. W. (2000) Globalization and the Theory of Input Trade. Cambridge MA, MIT Press.

Kadeřábková, A. and Srholec, M. (2001) Structural changes in transition economies. Prague Economic Papers, 6, pp. 335-351.

Kaminski, B. and Ng, F. (2001) Trade and Production Fragmentation: Central European Economies in EU Networks of Production and Marketing. Washington D.C., World Bank, Policy Research Working Paper 2611.

Kiszewski, A., Mellinger, A., Spielman, A. and Malaney, P. (2004) A global index of the stability of malaria transmission. American Journal of Tropical Medicine and Hygiene, 70, pp. 486-498.

Kogut, B. (1985) Designing global strategies: comparative and competitive value-added chains. Sloan Management Review, 26, pp. 15-28.

Krugman, P. (1995) Growing world trade: Causes and consequences. Brookings Papers on Economic Activity, 25, pp. 327-362.

Lall, S. (2000) The technological structure and performance of developing country manufactured exports, 1985-98. Oxford Development Studies, 28, pp. 337-369.

Lall, S., Albaladejo, M. and Zhang, J. (2004) Mapping fragmentation: Electronics and automobiles in East Asia and Latin America. Oxford Development Studies, 32, pp. 407-432.

Le Bas, C. and Sierra, C. (2002) Location versus home country advantages in R\&D activities: Some further results of multinationals' locational strategies. Research Policy, 31, pp. 589609.

Lee, H. H. and Lloyd, P. J. (2002) Frontiers of Research in Intra-Industry Trade. New York, Palgrave Macmillan.

Lüethje, B. (2001) Electronics contract manufacturing: Transnational Production Networks, the Internet, and Knowledge Diffusion in Low-Cost Locations in Asia and Eastern Europe. Honolulu, East-West Center, Working Paper No. 18.

Mani, S. (2000) Exports of High Technology Products from Developing Countries: Is It a Real or Statistical Artifact? Maastricht, INTECH, Discussion Paper No. 2000-1.

Marsili, O. (2001) The Anatomy and Evolution of Industries. Cheltenham, Edward Elgar.

Mayer, J., Butkevicius, A. and Kadri, A. (2002) Dynamic Products in World Exports. Geneva, UNCTAD, Discussion Papers No. 159. 
Nelson, R. R. and Winter, G. W. (1982) An Evolutionary Theory of Economic Change. Cambridge (MA), Harvard University Press.

NSF (2002) Science and Technology Indicators 2002. Washington DC, National Science Board.

OECD (2003) Science, Technology and Industry Scoreboard 2003. Paris, OECD.

OECD (2005) Main Science and Technology Indicators. Paris, OECD.

Patel, P. and Pavitt, K. (1991) Large firms in the production of the worlds technology: An important case of non-globalisation. Journal of International Business Studies, 22, pp. 1-21.

Pavitt, K. and Patel, P. (1999) Global corporations and national systems of innovation: who dominates whom? In: Archibugi, D., Howells, J. and Michie, J., eds., Innovation Policy in a Global Economy, Cambridge, Cambridge University Press, 94-119.

Pavitt, K. (1984) Sectoral patterns of technical change: Towards a taxonomy and a theory. Research Policy, 13, pp. 343-373.

Peneder, M. (2003) Industry classifications: Aim, scope and techniques. Journal of Industry, Competition and Trade, 3, pp. 109-129.

Pol, E., Carroll, P. and Robertson, P. (2002) A new typology for economic sectors with a view to policy implications. Economics of Innovation and New Technology, 11, pp. 61-76.

Rosenberg, N. (1963) Technological change in the machine tool industry, 1840-1910. Journal of Economic History, 23, pp. 414-443.

RICYT (2005) Science and Technology Indicators. Buenos Aires, The Network on Science and Technology Indicators - Ibero-American and Inter-American.

Schumpeter, J. (1934) The Theory of Economic Development. Cambridge (MA), Harvard University Press.

Srholec, M. (2006) Global production systems and technological catching-up: Thinking twice about high-tech industries in emerging countries. In: Piech, K. and Radoševič, S., eds., The Knowledge-Based Economy in Central and East European Countries: Countries and Industries in a Process of Change, Palgrave Macmillan, New York, pp. 57-78, in print.

UNDP (2001) Human Development Report 2001: Making New Technologies Work for Human Development. Oxford, Oxford University Press.

UNCTAD (2002a) World Investment Report 2002: Transnational Corporations and Export Competitiveness. Geneva, UNCTAD.

UNCTAD (2002b) Trade and Development Report 2002: Export Dynamism and Industrialization in Developing Countries. Geneva, UNCTAD.

UNIDO (2002) Industrial Development Report 2002/2003: Competing through Innovation and Learning. Vienna, UNIDO.

United Nations (2005) Comtrade Database. New York, The United Nations Statistics Division.

UNESCO (2005) Science and Technology Indicators. Canada, UNESCO Institute for Statistics.

Verspagen, B. (1993) Uneven Growth Between Interdependent Economies. Aldershot, Edward Elgar. 
Verspagen, B. and Schoenmakers, W. (2004) The spatial dimension of patenting by multinational firms in Europe. Journal of Economic Geography, 4, pp.23-42.

Wooldridge, J. M. (2002) Econometric Analysis of Cross Section and Panel Data. Cambridge MA, MIT Press.

World Bank (2005) The World Development Indicators 2005. New York, The World Bank.

Yeats, A. (2001) Just how big is global production sharing? In: Arndt, S. and Kierzkowski, H., eds., Fragmentation: New Production and Trade Patterns in the World Economy, Oxford, Oxford University Press, pp. 108-143.

Young, A. A. (1928) Increasing Returns and Economic Progress. The Economic Journal, 38, pp. 527-542. 
Appendix 1: Overview of trade in electronics (\% of total exports + imports)

\begin{tabular}{|c|c|c|c|c|c|c|c|}
\hline & 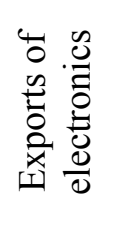 & 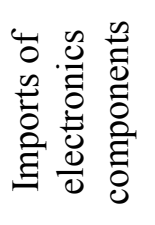 & 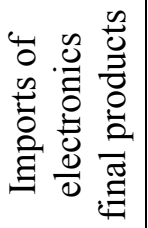 & & 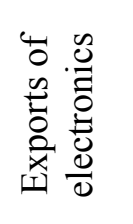 & 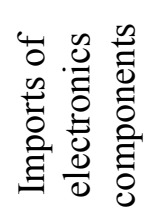 & 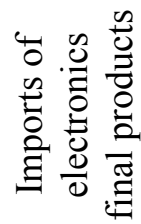 \\
\hline Philippines & 34.28 & 24.67 & 2.26 & Spain & 3.83 & 2.83 & 4.63 \\
\hline Malaysia & 30.83 & 19.74 & 3.61 & Turkey & 3.64 & 2.98 & 3.51 \\
\hline Singapore & 29.81 & 16.46 & 5.88 & Belarus & 3.50 & 2.09 & 1.98 \\
\hline Malta & 24.92 & 17.90 & 2.96 & Canada & 3.40 & 3.21 & 4.35 \\
\hline Hong Kong & 22.93 & 14.75 & 8.21 & Croatia & 3.34 & 2.80 & 6.65 \\
\hline Taiwan & 22.78 & 9.26 & 6.09 & Brazil & 2.85 & 4.57 & 2.80 \\
\hline Korea & 20.40 & 8.98 & 4.36 & New Zealand & 2.76 & 2.51 & 5.68 \\
\hline China & 18.87 & 11.68 & 5.64 & Bulgaria & 2.70 & 2.94 & 3.94 \\
\hline Ireland & 18.74 & 6.95 & 4.64 & Norway & 2.42 & 2.21 & 3.76 \\
\hline Hungary & 18.38 & 9.81 & 6.03 & Australia & 2.13 & 3.26 & 7.38 \\
\hline Costa Rica & 17.94 & 11.68 & 5.93 & Mauritius & 2.12 & 1.71 & 4.09 \\
\hline Japan & 17.35 & 4.96 & 4.92 & Jordan & 2.04 & 2.24 & 3.55 \\
\hline Mexico & 17.22 & 9.64 & 5.22 & Armenia & 2.00 & 2.13 & 3.47 \\
\hline Thailand & 17.01 & 9.39 & 4.42 & Latvia & 1.77 & 2.88 & 5.19 \\
\hline Finland & 14.28 & 4.70 & 4.67 & Namibia & 1.68 & 2.34 & 3.71 \\
\hline Netherlands & 13.46 & 5.40 & 7.73 & India & 1.67 & 2.61 & 3.82 \\
\hline Israel & 10.36 & 3.60 & 5.48 & South Africa & 1.57 & 2.98 & 5.80 \\
\hline Czech Republic & 10.26 & 6.23 & 5.02 & Greece & 1.54 & 2.53 & 5.44 \\
\hline Switzerland & 9.73 & 2.52 & 4.74 & Kyrgyzstan & 1.49 & 1.01 & 2.86 \\
\hline Sweden & 9.21 & 3.52 & 4.93 & Barbados & 1.44 & 3.62 & 8.98 \\
\hline United States & 9.14 & 4.96 & 8.51 & Sri Lanka & 1.35 & 1.66 & 2.67 \\
\hline Germany & 9.04 & 3.78 & 4.30 & Macedonia, FYR & 1.30 & 1.49 & 4.61 \\
\hline Estonia & 8.41 & 5.91 & 5.93 & Russia & 0.90 & 1.97 & 4.72 \\
\hline Indonesia & 8.39 & 0.96 & 1.43 & Lebanon & 0.78 & 1.75 & 5.03 \\
\hline United Kingdom & 8.23 & 3.88 & 6.67 & Oman & 0.77 & 2.09 & 1.34 \\
\hline Slovenia & 7.60 & 3.17 & 3.09 & Moldova & 0.72 & 1.66 & 3.16 \\
\hline France & 6.72 & 3.27 & 4.61 & Colombia & 0.69 & 1.54 & 6.69 \\
\hline Denmark & 6.53 & 3.03 & 5.21 & Argentina & 0.68 & 1.60 & 2.61 \\
\hline Austria & 6.23 & 3.35 & 4.33 & Guatemala & 0.67 & 1.86 & 5.80 \\
\hline Portugal & 6.04 & 4.51 & 4.31 & El Salvador & 0.64 & 2.18 & 5.41 \\
\hline Tunisia & 6.02 & 4.90 & 3.28 & Pakistan & 0.61 & 1.18 & 2.76 \\
\hline Slovakia & 5.50 & 4.57 & 3.36 & Rwanda & 0.57 & 3.65 & 7.49 \\
\hline Morocco & 5.43 & 3.52 & 3.74 & Cyprus & 0.53 & 2.68 & 6.84 \\
\hline Poland & 5.34 & 3.64 & 4.14 & Bolivia & 0.48 & 1.28 & 2.76 \\
\hline Italy & 5.06 & 2.44 & 3.82 & Cote d'Ivoire & 0.40 & 0.72 & 1.30 \\
\hline Romania & 4.43 & 4.46 & 4.51 & Senegal & 0.38 & 1.68 & 2.49 \\
\hline Belgium & 4.26 & 1.73 & 3.09 & Venezuela & 0.38 & 1.05 & 2.21 \\
\hline Lithuania & 4.05 & 2.69 & 3.74 & Kenya & 0.37 & 1.16 & 3.07 \\
\hline
\end{tabular}

Continue on the next page 
Continuing from the previous page

\begin{tabular}{|c|c|c|c|c|c|c|c|}
\hline & 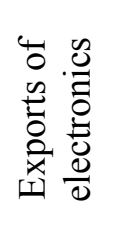 & 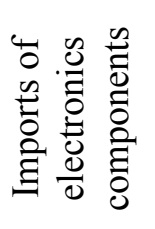 & 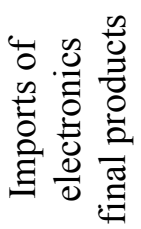 & & 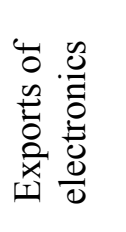 & 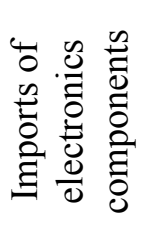 & 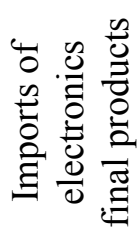 \\
\hline Madagascar & 0.36 & 1.83 & 3.52 & Malawi & 0.10 & 1.53 & 3.26 \\
\hline Iceland & 0.35 & 3.30 & 5.12 & Niger & 0.09 & 1.16 & 4.92 \\
\hline Albania & 0.31 & 3.55 & 4.03 & Nepal & 0.09 & 2.54 & 3.33 \\
\hline Trinidad and Tobago & 0.31 & 0.95 & 2.19 & Uganda & 0.08 & 2.01 & 8.49 \\
\hline Uruguay & 0.30 & 1.69 & 2.41 & Fiji & 0.08 & 2.23 & 3.82 \\
\hline Kazakhstan & 0.28 & 1.83 & 2.78 & Guyana & 0.07 & 1.38 & 1.52 \\
\hline Honduras & 0.25 & 2.29 & 5.48 & Central African Rep. & 0.07 & 1.14 & 1.82 \\
\hline Chile & 0.24 & 1.63 & 4.31 & Nicaragua & 0.07 & 2.33 & 7.41 \\
\hline Georgia & 0.20 & 2.04 & 3.97 & Egypt & 0.07 & 2.70 & 2.61 \\
\hline Cameroon & 0.20 & 1.18 & 2.42 & Azerbaijan & 0.06 & 2.16 & 2.75 \\
\hline Peru & 0.19 & 1.49 & 5.11 & Togo & 0.04 & 0.87 & 1.21 \\
\hline Iran & 0.16 & 1.96 & 2.67 & Bangladesh & 0.04 & 0.96 & 1.96 \\
\hline Ecuador & 0.16 & 1.91 & 6.52 & Panama & 0.02 & 2.68 & 7.96 \\
\hline Tanzania & 0.15 & 2.14 & 3.57 & Mongolia & 0.02 & 2.36 & 2.70 \\
\hline Bahrain & 0.14 & 1.59 & 1.52 & Nigeria & 0.02 & 1.31 & 2.15 \\
\hline Gabon & 0.14 & 1.10 & 1.63 & Algeria & 0.01 & 1.85 & 2.92 \\
\hline Belize & 0.13 & 2.16 & 4.16 & Ethiopia & 0.00 & 3.11 & 7.10 \\
\hline Syria & 0.11 & 1.38 & 2.04 & & & & \\
\hline
\end{tabular}


Appendix 2: Correlation Table

\begin{tabular}{|c|c|c|c|c|c|c|c|c|c|c|c|}
\hline & $\stackrel{\Xi}{\Xi}$ & 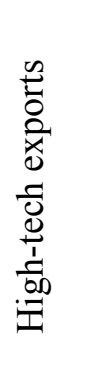 & 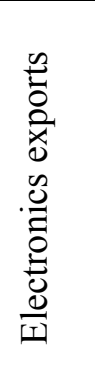 & 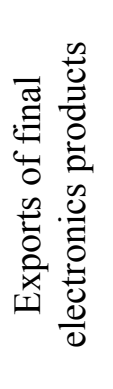 & 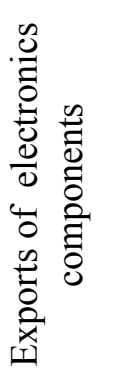 & 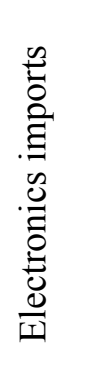 & 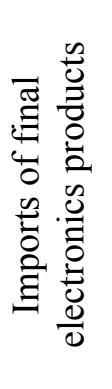 & 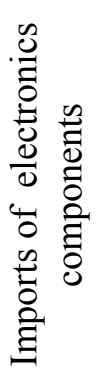 & 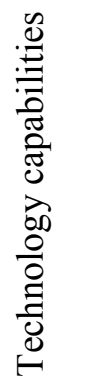 & 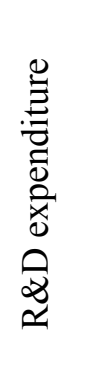 & 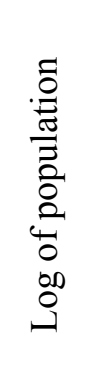 \\
\hline High-tech exports & \multirow{7}{*}{ 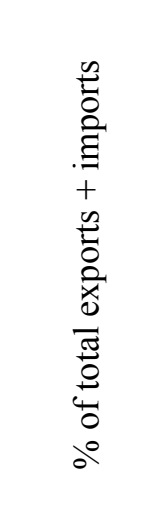 } & 1 & 0.92 & 0.79 & 0.90 & 0.77 & 0.13 & 0.84 & 0.49 & 0.39 & 0.15 \\
\hline Electronics exports & & & 1 & 0.89 & 0.96 & 0.86 & 0.20 & 0.92 & 0.46 & 0.33 & 0.15 \\
\hline Exports of final electronics products & & & & 1 & 0.71 & 0.71 & 0.27 & 0.71 & 0.56 & 0.45 & 0.22 \\
\hline Exports of electronics components & & & & & 1 & 0.86 & 0.14 & 0.95 & 0.34 & 0.21 & 0.09 \\
\hline Electronics imports & & & & & & 1 & 0.55 & 0.93 & 0.33 & 0.18 & 0.07 \\
\hline Imports of final electronics products & & & & & & & 1 & 0.21 & 0.36 & 0.26 & -0.01 \\
\hline Imports of electronics components & & & & & & & & 1 & 0.23 & 0.10 & 0.09 \\
\hline Technology capabilities & index & & & & & & & & 1 & 0.87 & 0.01 \\
\hline R\&D expenditure & $\%$ of GDP & & & & & & & & & 1 & 0.03 \\
\hline Log of population & $\operatorname{logs}$ & & & & & & & & & & 1 \\
\hline \multicolumn{2}{|l|}{ Number of observations } & 111 & 111 & 111 & 111 & 111 & 111 & 111 & 111 & 83 & 111 \\
\hline
\end{tabular}


Appendix 3: Instrumental variables for the two-stage least squares estimate

\begin{tabular}{|c|c|}
\hline Instruments: & Sources: \\
\hline Longitude and latitude of country centroid (in degrees) & $\begin{array}{l}\text { Gallup, Sachs and Mellinger (1999) } \\
\text { - CID Geography Datasets }\end{array}$ \\
\hline $\begin{array}{l}\text { Malaria Ecology - ecologically-based spatial index of the } \\
\text { stability of malaria transmission based on the interaction of } \\
\text { climate with the dominant properties of anapheline vectors } \\
\text { of malaria that determine vectorial capacity (index from } 0 \\
\text { to } 100 \text { ) }\end{array}$ & Kiszewski, et al. (2004) \\
\hline $\begin{array}{l}\text { Ethnic fractionalization - the probability that two randomly } \\
\text { selected people from a given country will not belong to the same } \\
\text { ethnic group (index from } 0 \text { to } 1 \text { ) }\end{array}$ & Alesina, et al. (2003) \\
\hline $\begin{array}{l}\text { Religious fractionalization - the probability that two } \\
\text { randomly selected people from a given country will not } \\
\text { belong to the same religious group (index from } 0 \text { to } 1 \text { ) }\end{array}$ & Fearon and Laitin (2003) \\
\hline$\%$ of urban population & World Bank (2005) \\
\hline $\begin{array}{l}\% \text { of the population within } 100 \mathrm{~km} \text { of the ocean or ocean- } \\
\text { navigable river, excluding coastline above the winter extent } \\
\text { of sea ice and the rivers that flow to this coastline. }\end{array}$ & $\begin{array}{l}\text { Gallup, Sachs and Mellinger (1999) } \\
\text { - CID Geography Datasets }\end{array}$ \\
\hline $\begin{array}{l}\text { The timing of national independence - } 0 \text { if before 1914; } 1 \text { if } \\
\text { between } 1914 \text { and } 1945 ; 2 \text { if between } 1946 \text { and 1989; and } 3 \text { if } \\
\text { after } 1989\end{array}$ & $\begin{array}{l}\text { Gallup, Sachs and Mellinger (1999) } \\
\text { - CID Geography Datasets }\end{array}$ \\
\hline
\end{tabular}

